Egyptian Journal for Aquaculture

P-ISSN: 2090-7877

E-ISSN: 2636-3984

www.eja.journals.ekb.eg/

Moustafa et al., 2021; 11 (1):33-54

DOI: 10.21608/eja.2021.90477.1057

\title{
Study of Nitrogen and Phosphorus transformations in cement ponds of Nile tilapia fry.
}

Yasser T. A., Moustafa ${ }^{1 *}$; Ahmed, A. A. Ali ${ }^{2}$; and Mohamad, F. ElDahshouri $^{3}$

${ }^{1}$ Limnology department, ${ }^{2}$ Fish physiology and hatchery Department, Central Laboratory for Aquaculture Research(CLAR), Agriculture Research Centre(ARC), Egypt.

3 Fertilization Technology Department, National Research Centre (NRC), Egypt.

*Correspondence: E-mail: ymoustafaonline@yahoo.com

Received: Jan 21, 2021; Accepted: March 09, 2021 published: 2021 Vol.11 (1):33-54

\section{ABSTRACT}

The ever-expanding of aquaculture activities raised concerns about the unknown detrimental effects of high effluent loading on the aquatic ecosystems. Therefore, this study quantified the accumulation of nitrogen $(\mathrm{N})$ and phosphorus $(\mathrm{P})$ in different forms in the water, sludge and fry in rearing ponds. Four ponds were assigned in a Nile tilapia hatchery of private sector to study the nutrient mass balance and the chemical composition of the sludge, in two fry production cycles, each for 25 days divided into three periods, during April-June 2021.

The results showed that, every $\mathrm{Kg}$ feed (45\% protein) produces $420 \mathrm{~g}$ sludge and $355.94 \mathrm{~g}$ suspended solids, 50\% out of which settled at the bottom. Fry retained $27.6 \%$ and $20.4 \%$ of the applied dietary nitrogen and phosphorus, respectively. Accumulation of $\mathrm{TN}$ and $\mathrm{TP}$ in the sludge accounted for $16.6 \%$ of the dietary $\mathrm{N}$ and $50 \%$ of the dietary P. Effluent water contained $29.16 \%$ and $25.8 \%$ of introduced dietary nitrogen and phosphorus, respectively, distributed in different forms. The dietary nitrogen recovery in the present study was $73.38 \%$, suggesting considerable role for ammonia volatilization, denitrification and anammox processes in the $\mathrm{N}$-losing and almost no $\mathrm{N}$-fixation occur in these ponds, while the phosphorus recovery reached $96 \%$. The results also showed that the fry rearing ponds threaten 
the environment, as their effluent and sludge are rich in nutrients.

Thus, it is recommended to utilize the fry ponds effluent in microalgae production and recycle the sludge into vermicompost fertilizer.

Key words: Nitrogen and Phosphorus mass balance, Nile tilapiahatchery, Oreochromis niloticus, nutrient transformation, fry production.

\section{INTRODUCTION}

Aquaculture is the only mean for bridging the gap between supply and demand of many farmed species. However, as aquaculture has been tremendously successful and expanding over the time, more concerns are rising by the environmental advocate groups over the aquaculture impact on the aquatic environment (Naylor et al., 2000). Therefore, aquaculture industry has to respond to these environment concerns in a responsible manner by developing more sustainable production techniques, with efficient management for aquaculture wastes treatment. To achieve such responsible systems, it is necessary to fully understand the nature of the pollutant nutrients and their transformation clearly. Several studies have documented the nutrients budget in several fish species production systems (Moustafa et al., 2020). Nevertheless, there is a serious dearth of literature focusing on the nutrients budget in the fry rearing ponds in the hatcheries.

Artificial feed-based aquaculture has become the standard production technique for many species globally. Aquaculture feeds are usually containing 4 to $8 \%$ nitrogen and 0.8 to $1.5 \%$ phosphorus. Thus, nutrients are generated, as a result of the feeding process, in dissolved or particulate forms enriching aquaculture effluent, which results in eutrophication the receiving water bodies (Warren-Hansen 1982). Since nitrogen use efficiency ranged from $11.7 \%$ to $27.7 \%$, whereas phosphorus use efficiency ranged from $8.7 \%$ to $21.2 \%$ (Zhang et al., 2015), which means more than $70 \%$ of the applied amount of feed's nutrients are waste load. According to Shwartz and Boyd (1994), the effluents of catfish earthen ponds contain $28.5 \%$ of $\mathrm{N}$ and $7 \%$ of $\mathrm{P}$ applied in feeds. Moreover, Boyd (1985) showed that nutrients resulted from a 1000 channel catfish production result in $2500 \mathrm{Kg}$ dry phytoplankton.

The production of tilapia in Egypt reached around 1 million tonnes in 2017(FAO 2020) representing an economic value of 35 billion Egyptian 
pounds. This production necessitates a large number of hatcheries to meet the demand on Nile tilapia fry. However, there is scarce information describing the nitrogen and phosphorus dynamic in the rearing ponds of the Nile tilapia fry. Therefore, the present study aimed to determine the amounts of nitrogen and phosphorus that are generated by the fry tilapia rearing concrete ponds and their transformations in the ponds effluent as well as in the sludge, through characterized nitrogen and phosphorus fractions. So, a more efficient mean can be developed to eliminate or at least reduce the negative impacts of hatcheries effluents on the aquatic environment.

\section{MATERIALS AND METHODS}

\section{Experimental design}

The present study was designed to study the nitrogen and phosphorus transformations, nutrients mass balance and characterize the effluent and sludge of Nile tilapia fry's cement ponds, in a Nile tilapia hatchery of a private sector, in Kafer El-Shikh Governorate.

During two successive fry culture cycles on $21^{\text {st }}$ April 2021 through

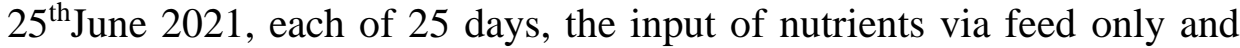
nutrients loss in fish biomass, nutrients settled in sludge and nutrients loads in the effluents are the environmental indicators that have been determined in this study.

To achieve that goal, four cement ponds with dimensions of $3.0 \times 7.0$ $\times 1.0 \mathrm{~m}$ were assigned for the environmental indicators determination in each culture cycle and filled with water at $80 \mathrm{~cm}$ depth, with a working volume of $16800 \mathrm{~L}$, and stocked with $50000\left(3000 \mathrm{fry} / \mathrm{m}^{3}\right)$ Nile tilapia fry of about $8 \mathrm{mg}$ in each pond. The daily feeding rate was applied adlibitum feeding for $15 \mathrm{~min}$, introduced three times daily between 9:00 and 18:00 using feed of $7.2 \%$ nitrogen and $0.8 \%$ phosphorus contents.

To get reliable data, two fry production cycles were carried out. Each cycle continued for 25 days, and divided into three periods, 12, 8 and 5 days. At the beginning of the second and third periods, $50 \%$ of the water within each pond was discharged to reduce the nutrients concentrations to avoid any threat on the fry survival. After those ponds were refilled to the water depth of $80 \mathrm{~cm}$ and the water nutrients concentrations were determined and considered as the baseline for the period. At the end of each period the water nutrient concentrations were determined to calculate the Nutrients Mass Balance (NMB) as a result of the feeding process. At the end of each fry production cycle the data of the three 
periods were accumulated and gathered to determine the overall concentration of the nutrients and their transformation.

\section{Nutrient budgets and mass balance}

The considered nutrient gains source was feed while considered nutrient losses were the gain weight of harvested fry, drainage water and determined pond sediment (sludge).

To estimate total nutrient gains from feed, feed proximate analyses were made for total nitrogen as well as total phosphorus contents.

To estimate nutrient contribution of affluent water in the first period of each fry production cycle, water samples were collected from the inlet pipe during ponds filling and their different forms of nitrogen and phosphorus contents were determined. To calculate the nutrient contribution from feed in the ponds water (Nutrients Mass Balance, $\mathrm{NMB})$, the nutrient load in affluent water $\left(\mathrm{L}_{\mathrm{A}}\right)$ was subtracted from the effluent nutrient load $\left(\mathrm{L}_{\mathrm{E}}\right)$ at the end of each period (12, 8 and 5 days per fry production cycle), according to the following Equation (Boyd and Queiroz, 2001; Boyd et al., 2007; Osti et al., 2018):

$$
\mathrm{NMB}=\mathrm{LE}_{\mathrm{E}}-\mathrm{L}_{\mathrm{A}}
$$

Where: $\mathrm{NMB}=$ nutrients mass balance loads of $(\mathrm{TP}$ and $\mathrm{TN})$

For considered losses in sludge, sediments volume and weight in each pond were calculated after fry harvest and its $\mathrm{TN}$ and $\mathrm{TP}$ were determined. To measure $\mathrm{N}$ and $\mathrm{P}$ loose in fry biomass, final fry samples, at the end of the production cycles, were collected and their TN and TP were determined and multiply in the weight gain, assuming that nitrogen and phosphorus content \% did not change (Jimenez-Montealegre et al., 2005).

\section{Sludge of different sources determination:}

Water TSS: The volume of water added to ponds was estimated by monitoring water levels in each fish pond. Gradual signs $(100 \mathrm{~cm}$ high) were marked on the cement ponds walls to monitor changes in ponds water depth and volume. The total suspended solids were determined according to APHA (1985).

Feed: Commercial feed (7.2\% nitrogen) was used throughout the experiment and the quantity of feed inputs into the fry ponds were introduce three times daily (between 9:00 and 18:00) and recorded daily then quantified at the end of each fry production cycle (25 days) and the feed contribution to sludge accumulation was estimated. 
To get the sludge volume and weight in each pond at the end of each fry production cycle, the fry were collected after the water depth reduced to $50 \mathrm{~cm}$, then aeration stopped and the water within the pond left for $24 \mathrm{~h}$ for settlement, to get concentrated sludge. On the next day the water was discarded to the minimum water depth $10 \mathrm{~cm}$. To determine the dry weight sludge, three water samples, each of $2000 \mathrm{ml}$ volume, were taken and left to be settled for another $24 \mathrm{~h}$. The dry weight of the collected sludge was determined using drying oven for $48 \mathrm{~h}$ on $70^{\circ} \mathrm{C}$.

Total amount of sludge $(\mathrm{Kg})=$ (volume of concentrated sludge $\times$ dry weight of sludge in samples) / $2000 \mathrm{ml}$ (volume of sample)

\section{Chlorophyll "a"}

Chlorophyll "a" was determined as indicator for phytoplankton. Phytoplankton is considered a considerable source for sludge, since 50\% of the phytoplankton settles at the bottom of the fry ponds daily (Schroeder et al., 1991).

\section{Chemical analysis:}

Total nitrogen in sludge, fish and feed was analyzed by the Kjeldahl method (APHA, 1985). The total phosphorus content in sludge; fish and feed were determined by using dry ash method (Tavares and Boyd, 2003) for digestion then phosphorus was colorimetrically estimated using the vanadomolybdate method (APHA, 1985).

Affluent and effluent water samples were collected at the beginning and ending of each period, from each pond for analysis and determination of : total solids (TSS), $\mathrm{NH}_{4} ; \mathrm{NO}_{2} ; \mathrm{NO}_{3}$, total nitrogen of sample before filtration (TN); Total dissolved nitrogen (TDN) of sample after filtration; total phosphorus of sample before filtration (TP); total dissolved phosphorus (TDP) of sample after filtration and orthophosphate (OP) according to the analytical methods of APHA (1985).

Particulate nitrogen (Part. N); particulate phosphorus (Part. P); dissolved organic nitrogen (DON); and dissolved organic phosphate (DOP) were calculated.

\section{Calculations:}

Total nutrient (Nitrogen / Phosphorus) input per pond $\left(\mathrm{TN}_{\mathrm{I}}\right)=$ Total amount of applied feed $(\mathrm{kg}) \times$ average of dry matter fraction $\times$ average of nutrient (nitrogen/Phosphorus) content in dry feed (Kg) by $\mathrm{Kg}$ of feed

Nutrient loss in fish biomass was calculated as following equation (Boyd and Queiroz, 2001; Boyd et al., 2007):

$$
\mathrm{N}_{\mathrm{B}}=\mathrm{P} \times \mathrm{DM} \times \mathrm{N}_{\mathrm{DM}}
$$


Where: NB = converted nutrient in fish biomass $(\mathrm{kg}$ of TP or TN), $\mathrm{P}=$ fish gain weight $(\mathrm{kg})$ at the end of each culture trial, $\mathrm{DM}=$ amount of dry matter by kilogram of fish (kg), $\mathrm{N}_{\mathrm{DM}}=$ amount of nutrient $(\mathrm{TP}$ or $\mathrm{TN})$ by kilogram of dry matter of fish $(\mathrm{kg})$.

According to Thoman et al., (2001) the following equations have been used to determine different fractions of nutrients in water.

Particulate nitrogen $=$ total nitrogen $(\mathrm{TN})$ before sample filtration TDN after sample filtration

Dissolved inorganic nitrogen $(\mathrm{DIN})=\mathrm{NH}_{4}+\mathrm{NO}_{2}+\mathrm{NO}_{3} \mathrm{mg} / \mathrm{L}$

Dissolved organic nitrogen $(\mathrm{DON})=\mathrm{TDN}$ after sample filtration DIN

Particulate phosphorus $=$ total phosphorus $(\mathrm{TP})$ before sample filtration - TDP after sample filtration

Dissolved organic phosphorus $(\mathrm{DOP})=$ TDP after sample filtration Orthophosphate

Total Nutrients Recovery \% (TNR; per tank) $=\%$ Nutrient (N/P) Fish $+\%$ Nutrient in sludge $+\%$ inorganic fraction of nutrient (DIN/OP) in water $+\%$ organic Nutrient $(\mathrm{DON} / \mathrm{DOP})$ in water + particulate nutrients (Part. N/Part. P) in water.

Chlorophyll a was determined using acetone 90\% extraction and measuring absorbance at 665 and $750 \mathrm{~nm}$ (APHA, 1985). Nitrogen content in the chlorophyll "a" was calculating assuming the ratio of $5 \mathrm{mg}$ $\mathrm{N} 1 \mathrm{mg}^{-1}$ of chlorophyll "a" (Laws \& Bannister 1980).

\section{RESULTS AND DISCUSSION}

\section{Fry growth:}

At the beginning of each fry production cycle, the fry were stocked at a biomass of $400 \mathrm{~g}$ in each pond. At the end of the production cycles, after 25 days per cycle, the survival rate was $81.7 \pm 3.7 \%$ and the average fry biomass was $12.25 \pm 0.56 \mathrm{Kg} /$ pond. The feed intake was of $15.59 \pm 0.66 \mathrm{~kg} /$ pond / 25days and FCR was $1.32 \pm 0.03$. Harvested fry have $\mathrm{N}$ content of $2.61 \%$, and P content of $0.215 \%$. Higher FCR (1.6 \pm 0.2 ) was reported for fry Nile tilapia with average weight $9.0 \pm 1.0 \mathrm{mg}$ (Arredondo-Figueroa et al., 2015). The lower FCR in the present study may be explained by assuming that the fish utilized detrital and planktonic feed between meals during the rearing period to support the smooth growth (Jimenez-Montealegre et al., 2005).

The survival rate in the present study was $81.7 \pm 3.7 \%$. Lower mean mortality $(5 \%)$ was reported for Nile tilapia fry $(9.0 \pm 1.0 \mathrm{mg})$ reared in 
RAS system by Arredondo-Figueroa et al., (2015). This lower mortality can be attributed to different culture conditions, water filtration and water flow rate.

\section{TSS:}

TSS in affluent water was found to be $8.3 \mathrm{mg} / \mathrm{liter}$ and produced about140 gm sediment/pond of the $16.8 \mathrm{~m}^{3}$ working volume. The accumulated TSS as a result of feeding was determined, for each fry production cycle, in the present work to be $330.3 \pm 51.6 \mathrm{mg} / \mathrm{liter}$ and produced about $5549.1 \pm 886.7 \mathrm{gm}$ suspended solids/pond of $16800 \mathrm{~L}$ working volume per fry production cycle, half of them settled on the bottom. The total determined sludge / pond was found $9321.3 \mathrm{~g} / \mathrm{pond} / 25$ days. Then the settled uneaten feed and fish excretion generate about $6546.75 \mathrm{~g} /$ pond. Based on that, each $\mathrm{kg}$ feed produced $355.94 \mathrm{~g}$ of suspended solid, assuming half of them settled at the bottom of the pond that means $177.95 \mathrm{~g}$ settled solid/ $\mathrm{kg}$ feed, which represents about 29.77 $\%$ of the total produced sludge $(598.6 \mathrm{~g} / \mathrm{kg}$ feed, $9321.3 \mathrm{~g} / \mathrm{pond})$ at the end of the fry production cycle, and about $419.93 \mathrm{gm}$ sludge $/ \mathrm{kg}$ feed, which represent $70.23 \%$ of the total produced sludge per $\mathrm{Kg}$ feed. Moustafa et al. (2020) found that every $\mathrm{kg}$ feed produce $420 \mathrm{~g}$ of sludge as fish solid excretion and uneaten feed, which represented $62.4 \%$ of the total produced sludge.

According to the literatures, every $\mathrm{Kg}$ feed produces about $412 \mathrm{gm}$ sludge (Muendo et al., 2014). Summerfelt et al. (2001) calculated that every kilogram of fed feed emits $0.43 \mathrm{~kg}$ of suspended solids, additional 9\% suspended solids of feed emerge from activity of heterotrophic organisms and another $0.09 \%$ - due to activity of nitrification bacteria.

Aquaculture sludge has negatively impact on fry survival as well as growth performance due to unpredictable release of toxic elements such as hydrogen sulfides and nitrites. Organic matter deposition is concomitant with a high oxygen demand and lead to oxygen depletion (Boyd and Tucker 1995). Lin and Yi (2003) reported that although the aquaculture sludge is a waste of valuable nutrients, nevertheless, it threats environment. Therefore, it is necessary to search for a suitable treatment before using it, i.e., vermicomposting (Kouba $\boldsymbol{e t}$ al., 2018; Moustafa $\boldsymbol{e t}$ al., 2020; Gomha et al., 2020).

\section{Chlorophyll "a"}

In the present study the chlorophyll "a" was found to be at $4.99 \pm 1.04$ $\mu \mathrm{g} / \mathrm{L}$, which means $83.8 \pm 17.4 \mathrm{mg} /$ pond. Assuming the ratio $5 \mathrm{mg} \mathrm{N}$ 
per 1 mg chlorophyll "a" (Laws \& Bannister 1980). Then the Chlorophyll "a" $\mathrm{N}$ content is $419.0 \pm 87.0 \mathrm{mg}$ / pond.

\section{Nitrogen gains}

Introduced feed was $7.2 \% \mathrm{~N}$ and $0.8 \% \mathrm{P}$. An average of $15.59 \pm 0.66$ $\mathrm{kg}$ of feed containing $1122.3 \pm 47.5 \mathrm{~g} \mathrm{~N}$ (average of $2.67 \mathrm{~g} \mathrm{~m}^{-3} \mathrm{~d}^{-1}$ ) was applied to each pond in 25 days of fry production cycle. Feed accounted for almost $100 \%$ of $\mathrm{N}$ entering ponds.

The TN : TP molar ratio average was higher than 22 suggesting inhibited $\mathrm{N}$-fixation process in the fry ponds in the present study. Hence, $\mathrm{N}$-fixer cyanobacterium overcome $\mathrm{N}$ shortage (at low TN : TP ratio) through $\mathrm{N}$ fixation while other species halt in their growth. Gross et al., (2000) reported that $\mathrm{N}_{2}$ fixation by symbiotic bacteria and blue-green algae is suppressed by increasing concentrations of TAN. Findlay $\boldsymbol{e t} \boldsymbol{a l}$. (1994) and Hendzel et al. (1994) showed that a molar ratio of TN:TP above 13 completely inhibited $\mathrm{N}_{2}$-fixation and low $\mathrm{N}: \mathrm{P}$ stimulate $\mathrm{N}_{2}$ fixation cyanobacteria blooms. They suggested that a low TN : TP ratio causes phytoplankton to become $\mathrm{N}$ deficient and gives blue-green algae capable of fixing $\mathrm{N}_{2}$ a competitive advantage over other phytoplankton species. Moreover, Morris \& Lewis (1988) suggested DIN : TP ratio of 3 as a threshold value for $\mathrm{N}$ limitation. In the present study, the DIN : TP molar ratio was found to be 16.18 , indicating the inhibition of $\mathrm{N}$-fixation. Ferber et al. (2004) reported that nitrogen fixation can be accounted for about $28 \%$ of phytoplankton $\mathrm{N}$ at low DIN concentrations.

\section{Nitrogen losses:}

The affluent water contribution in nitrogen and phosphorus budget was calculated and deducted from different fractions of nitrogen and phosphorus data, so the feed became the only measured nutrients source as shown in tables of nitrogen and phosphorus (Tables 1\&2).

The data of the nitrogen budget is shown in Table (1), which includes nitrogen added in feed; nitrogen retained in fry; nitrogen lost in sludge as well as different nitrogen fractions lost in drainage water. Based on the proposed indicators, fry biomass increased from $400 \mathrm{~g}$ to $12251.3 \pm$ $561.2 \mathrm{~g}$ within 25 days retaining $309.32 \pm 14.65 \mathrm{~g} \mathrm{~N}$ pond $^{-1}(27.56 \pm 0.54$ $\%$ ) of the dietary nitrogen input as showed in Table (1). Moustafa et al. (2020) determined that the Nile tilapia brood-stock retained at least 25.8 $\pm 3.91 \%$ of the dietary $\mathrm{N}$ input. 
Table (1): Average concentrations \pm SD for different nitrogen $(\mathrm{N})$ fractions in fry Nile tilapia ponds at a private tilapia hatchery, Kafr EL-Shikh governorate.

\begin{tabular}{|c|c|c|c|c|c|c|c|c|c|c|}
\hline \multirow{3}{*}{$\begin{array}{l}\text { Parameter } \\
\text { Units }\end{array}$} & \multirow{3}{*}{$\begin{array}{l}\text { Feed N } \\
\text { input }\end{array}$} & \multirow{3}{*}{$\begin{array}{l}\text { N retained } \\
\text { in Fry }\end{array}$} & \multirow{3}{*}{$\begin{array}{l}\mathrm{N} \text { in } \\
\text { sludge }\end{array}$} & \multicolumn{6}{|c|}{ Water $\mathrm{N}$} & \multirow{3}{*}{$\begin{array}{c}\mathrm{N} \\
\text { Recovery }\end{array}$} \\
\hline & & & & \multicolumn{2}{|c|}{ TSS N } & \multicolumn{3}{|c|}{ DIN } & \multirow[b]{2}{*}{ DON } & \\
\hline & & & & $\begin{array}{c}\text { Ch "a" } \\
\text { N }\end{array}$ & $\begin{array}{c}\text { Non-Ch } \\
\text { "a" } \\
\text { N }\end{array}$ & $\mathrm{NH}_{4}$ & $\mathrm{NO}_{2}$ & $\mathrm{NO}_{3}$ & & \\
\hline $\mathrm{mg} / \mathrm{L}$ & & & & $\begin{array}{c}0.025 \\
\pm 0.005\end{array}$ & $\begin{array}{l}3.64 \pm \\
2.12\end{array}$ & $\begin{array}{l}1.39 \pm \\
0.402\end{array}$ & $\begin{array}{c}0.156 \pm \\
0.071\end{array}$ & $\begin{array}{c}12.55 \pm \\
1.169\end{array}$ & $\begin{array}{c}1.66 \pm \\
0.96\end{array}$ & \\
\hline g/pond & $\begin{array}{c}1122.3 \pm \\
47.56\end{array}$ & $\begin{array}{c}309.3 \\
\pm \\
14.65 \\
\end{array}$ & $\begin{array}{c}186.43 \\
\pm \\
9.91\end{array}$ & $\begin{array}{c}0.42 \pm \\
0.09\end{array}$ & $\begin{array}{c}61.15 \pm \\
35.59\end{array}$ & $\begin{array}{r}23.31 \\
\pm 6.75\end{array}$ & $\begin{array}{c}2.63 \pm \\
1.19\end{array}$ & $\begin{array}{c}210.82 \pm \\
19.64\end{array}$ & $\begin{array}{c}27.87 \pm \\
16.15\end{array}$ & $\begin{array}{c}821.94 \\
\pm \\
36.31\end{array}$ \\
\hline $\begin{array}{l}\% \text { of feed } \\
\mathrm{N}\end{array}$ & & $\begin{array}{c}27.56 \\
\pm \\
0.54 \\
\end{array}$ & $\begin{array}{c}16.62 \\
\pm \\
0.81\end{array}$ & $\begin{array}{l}0.04 \pm \\
0.008\end{array}$ & $\begin{array}{c}5.47 \pm \\
3.19\end{array}$ & $\begin{array}{c}2.09 \pm \\
0.63\end{array}$ & $\begin{array}{c}0.23 \pm \\
0.11\end{array}$ & $\begin{array}{c}18.86 \pm \\
2.37\end{array}$ & $\begin{array}{c}2.48 \pm \\
1.4\end{array}$ & $\begin{array}{c}73.38 \\
\pm \\
4.29 \\
\end{array}$ \\
\hline
\end{tabular}

Ch "a" $\mathrm{N}=$ chlorophyll "a" $\mathrm{N}, \mathrm{DON}=$ Dissolved organic nitrogen. Each value is an average of 8 replicate \pm standard deviation. 
Avnimelech and Kochba (2009) found that about 25\% of the protein ration given to tilapia with average weight of $20 \mathrm{~g} /$ fish is recovered in a biofloc system. Overall, only about $20-30 \%$ of the nitrogen applied as feed to fish is recovered in the fish upon harvest (Avnimelech and Ritvo, 2003, for more references see Jimenez-Montealegre et al., 2005). The rest is apparently excreted by the fish (Hepher, 1988). However, Gross et al. (2000) reported that catfish can retain about $36.98 \%$ of applied dietary nitrogen. It seems that the nutrient retention in fish (mainly nitrogen and phosphorus) may differ under different conditions such as fish age, fish species, and environmental conditions (Avnimelech and Kochba 2009).

The total estimated sludge was $9321.3 \pm 495 . \mathrm{g} g$ / pond containing $186.42 \pm 9.9 \mathrm{~g} \mathrm{~N} /$ pond or $16.6 \pm 0.81 \%$ of the dietary $\mathrm{N}$ input. However, Moustafa et al. (2020) found that sludge of the Nile tilapia brood-stock ponds contained $11.3 \pm 0.78 \%$ of the dietary $\mathrm{N}$ input. The higher $\mathrm{N}$ content in the present study can be explained by the higher protein content in the applied feed (45\% protein) compared to that study (35\%) and longer period of the present study ( 25 days in each cycle vs 15 days) which allowed longer period for more plankton activities in the fry ponds. Schroeder et al. (1991) reported that 50\% of the phytoplankton biomass deposits daily.

Nitrogen losses in the effluents during draining accounted for 326.19 $\pm 50.1 \mathrm{~g} \mathrm{~N} /$ pond which represents $29.16 \pm 4.95 \%$ of dietary $\mathrm{N}$ input including three main fractions: particulate $\mathrm{N}$; dissolved inorganic $\mathrm{N}$ and dissolved organic N. However, Moustafa et al. (2020) estimated that draining water of the Nile tilapia brood-stock ponds contains $43.64 \pm$ $6.45 \%$ of the feed nitrogen content. On the other hand, Osti et al. (2018) reported that $16 \% \mathrm{TN}$ which entered the system in the form of feed were exported by effluent.

Water TSS $\mathrm{N}$ in the present study was found to be $5.5 \pm 3.2 \%$ of the applied dietary $\mathrm{N}$, including $\mathrm{N}$ in chlorophyll "a" $(0.04 \pm 0.01 \%$ of the applied dietary $\mathrm{N})$ and non-chlorophyll "a" $\mathrm{N}(5.46 \pm 3.19 \%$ of the applied dietary N). Moustafa $\boldsymbol{e t}$ al. (2020) estimated the water TSS N fraction at $13.29 \pm 7.27 \%$ of the applied dietary $\mathrm{N}$. These differences may be partially explained by the differences of the nature of the water TSS. In the present study the TSS mainly consisted of planktonic and microbial population that have fast dynamic and short life span, while in the previous study the water TSS was mainly consisted of the non-living particles, as the experimental period was just 15 days, so there was not enough time to develop plankton and microbial communities. Also, it can 
be explained by the higher amount of feed with higher protein content that is applied in the present study compared to that amount and protein content of the applied feed in that study. Cripps and Bergheim (2000) reported that particulate wastes commonly contain $7-32 \%$ of the total nitrogen $(\mathrm{TN})$ and the remainder is in the dissolved fraction in wastewater.

The chlorophyll "a" content that was measured in the present investigation is lower than that measured in well fertilized fish ponds, although the existence of high DIN and TP in the present study, this may be attributed to the grazing pressure exerted by fry and zooplankton, but unfortunately the current investigation we did not determined zooplankton. Also, low chlorophyll "a" content of $\mathrm{N}$ may be attributed to limited orthophosphate in the water since the molar ratio of DIN / P was 141. Higgins et al. (2018) reported N/P molar ratio of 27:1 as a required level for balanced growth in phytoplankton.

The dissolved inorganic nitrogen constitutes $21.18 \pm 2.5 \%$ of the applied dietary $\mathrm{N}$, with nitrate being the major constituent, about (18.86 \pm $2.37 \%$ ) of the applied dietary $\mathrm{N}$, which indicating good aeration within the fry ponds. Jimenez-Montealegre et al. (2005) reported that the high nitrate level in the water is a good indicator for aerobic conditions within the fish pond. The high $\mathrm{NO}_{3}$ concentration may be attributed to the high TN : TP that found in the present study. Similarly, Ferber et al. (2004) reported that the relative contribution of $\mathrm{NO}_{3}^{-} \mathrm{N}$ to $\mathrm{N}$ nutrition increased with TN : TP ratio, while that of $\mathrm{NH}^{+}{ }_{4}-\mathrm{N}$ decreased. The low ammonia concentration in the present study may be explained be the volatilization and nitrification processes. Gross et al. (1999) reported that $\mathrm{NH}_{3}$ is volatilized from pond surfaces as oxidized to nitrate $\left(\mathrm{NO}_{3}{ }^{-}-\mathrm{N}\right)$ by nitrifying bacteria. Moustafa et al. (2020) found DIN to represent $10.78 \%$ of the applied dietary N. This difference can be attributed to the difference in the length period of the study, in the present study the period was 25 days which allow enough time for mineralization of the organic $N$ in the sediments. Summerfelt and Vinci (2003) and Jimenez-Montealegre et al. (2005) reported that the organic form of nitrogen needs 3-4 weeks, for mineralization through the microbial activity.

Dissolved organic $\mathrm{N}$ in the present study was found to represent 2.48 $\pm 1.4 \%$ of the dietary N. Both the high DIN and moderate DON levels are suggesting active dynamics of plankton and microbial communities, through daily settlement of 50\% phytoplankton and mineralization of the organic $\mathrm{N}$, that resulted in high DIN and moderate DON levels. 
Moustafa et al. (2020) found that the DON level in Nile tilapia broodstock about $19.57 \pm 4.31 \%$ of the applied dietary $\mathrm{N}$.

In the present study, the cumulative $\mathrm{N}$ recovery at the end of the experiment period was $73.38 \pm 4.29 \%$ of the applied dietary $\mathrm{N}$, meaning that the $\mathrm{N}$ budget in the studied ponds of Nile tilapia fry cannot be fully explained without consideration of $\mathrm{N}$ volatilization through different ways, nitrification and de-nitrification that produces $\mathrm{N}_{2} \mathrm{O}$, one of the greenhouse gases (Boyd and Tucker, 1998; Zhang et al., 2011), ammonia volatilization and anammox process that produce $\mathrm{N}_{2}$ (Dalsgaard and Thamdrup 2002). Losses of $\mathrm{N}$ volatilization were estimated by subtracting the sum of all other measured $\mathrm{N}$ losses from the measured $\mathrm{N}$ inputs (Gross et al., 2000). Gross, et al. (1999) stated existence of a positive linear correlations between the amount of feed applied and TAN concentration in the water and between TAN concentration and $\mathrm{NH}_{3}$ volatilization. Zimmo et al. (2004) also showed that ammonia volatilization rate correlates with $\mathrm{NH}_{3}$ concentration. Jimenez-Montealegre et al., (2005) found that almost no $\mathrm{N}$ volatilization occurred at low ammonium concentration and aerated pond. Some studies showed different rates of denitrification as $17.36 \%$ of the $\mathrm{N}$ loss (Gross et al., 2000). In agriculture ammonia volatilization and $\mathrm{N}_{2} \mathrm{O}$ emission is considered the common mechanisms of $\mathrm{N}$ loss (Oenema $\boldsymbol{e t}$ al., 2009). On the other hand, Hargreaves (1995) showed that denitrification rate varies with abundance of denitrifying bacteria, concentrations of $\mathrm{NO}_{3}-\mathrm{N}$ and DO. Gross et al. (2000) reported $\mathrm{NH}_{3}$ volatilization (12.5\%) and denitrification (17.4\%) among of the main $\mathrm{N}$ losses, which is matching with our results. Finally, Jaroszynski et al. (2012) concluded that a stable nitrogen removal rate through anammox process depends on maintaining free ammonia concentrations below 2 mg N L${ }^{-1}$ when the $\mathrm{pH}$ is maintained between 7 and 8 .

These results indicate that the effluent water of the fry rearing ponds has more negative effect than that reported by Moustafa et al. (2020) of Nile tilapia brood-stock pond since it has more nutrient concentrations and the nitrification and de-nitrification process play reasonable role in $\mathrm{N}$ loss producing $\mathrm{N}_{2} \mathrm{O}$. On the other hand, the brood-stock effluent has lower nitrogen thus, it may give chance for blue-green algae to bloom through $\mathrm{N}$-fixing capability. 
Table (2): Average concentrations \pm SD for different phosphorus $(\mathrm{P})$ fractions in fry Nile tilapia ponds at a private tilapia hatchery, Kafr EL-Shikh governorate.

\begin{tabular}{|c|c|c|c|c|c|c|c|c|c|c|}
\hline \multirow{5}{*}{$\mathrm{TP}$} & Parameters & \multirow{2}{*}{$\begin{array}{c}\text { Feed } \mathrm{P} \\
\text { input }\end{array}$} & \multirow{2}{*}{$\begin{array}{c}\mathrm{P} \\
\text { retained } \\
\text { in Fry }\end{array}$} & \multirow{2}{*}{$\begin{array}{l}\mathrm{P} \text { in } \\
\text { Sludge }\end{array}$} & \multicolumn{5}{|c|}{ Water P } & \multirow{2}{*}{$\begin{array}{c}\text { Recovery } \\
\%\end{array}$} \\
\hline & Units & & & & $\mathrm{TP}$ & TDP & Part P & DOP & $\mathrm{OP}$ & \\
\hline & $\mathrm{mg} / \mathrm{L}$ & & & & $\begin{array}{c}1.92 \\
\pm \\
0.13\end{array}$ & $\begin{array}{c}0.36 \\
\pm \\
0.06\end{array}$ & $\begin{array}{c}1.56 \\
\pm \\
0.1\end{array}$ & $\begin{array}{c}0.14 \\
\pm \\
0.04\end{array}$ & $\begin{array}{c}0.22 \\
\pm \\
0.03\end{array}$ & \\
\hline & $\mathrm{g} /$ pond & $\begin{array}{c}124.7 \\
\pm \\
5.28\end{array}$ & $\begin{array}{c}25.48 \\
\pm \\
1.2\end{array}$ & $\begin{array}{c}62.27 \\
\pm \\
3.31\end{array}$ & $\begin{array}{c}32.19 \\
\pm \\
2.14\end{array}$ & $\begin{array}{c}5.96 \\
\pm \\
0.96\end{array}$ & $\begin{array}{c}26.23 \\
\pm \\
1.67\end{array}$ & $\begin{array}{c}2.29 \\
\pm \\
0.72\end{array}$ & $\begin{array}{c}3.68 \\
\pm \\
0.49\end{array}$ & $\begin{array}{c}119.94 \\
\pm \\
6.01\end{array}$ \\
\hline & $\begin{array}{l}\% \text { of feed } \\
\mathrm{N}\end{array}$ & & $\begin{array}{c}20.4 \\
\pm \\
0.4\end{array}$ & $\begin{array}{c}50 \\
\pm \\
2.4\end{array}$ & $\begin{array}{c}25.8 \\
\pm \\
1.5\end{array}$ & $\begin{array}{c}4.8 \\
\pm \\
0.7\end{array}$ & $\begin{array}{c}21.1 \\
\pm \\
1.4\end{array}$ & $\begin{array}{c}1.8 \\
\pm \\
0.6\end{array}$ & $\begin{array}{c}2.9 \\
\pm \\
0.4\end{array}$ & $\begin{array}{c}96.2 \\
\pm \\
3.9\end{array}$ \\
\hline
\end{tabular}

phosphorus, TDP $=$ Total dissolved phosphorus, Part $\mathrm{P}=$ particulate phosphorus, $\mathrm{DOP}=$ Dissolved organic phosphorus and $\mathrm{OP}=$ ortho-phosphate. Each value is an average of 8 replicate \pm standard deviation. 


\section{Phosphorus budget:}

The dietary phosphorus input was found to be $124.7 \pm 5.28 \mathrm{~g} /$ pond / 25 days (Table 2). Nile tilapia fry was found to retain $20.4 \pm 0.4 \%$ of the applied dietary phosphorus. It has been well documented that fish species as well as phosphorus source can significantly influence the $\mathrm{P}$ retention and loss in fish. Salmonids utilize phosphorus from fish meal more efficiently than do carp (Yone and Toshima 1979) whereas availability to tilapia is low. Moustafa et al. (2020) found that the Nile tilapia broodstock retained at least $2.74 \pm 0.37 \%$ of the feed phosphorus content. A percent of $10.02-15.10 \% \mathrm{P}$ from the total $\mathrm{P}$ inputs was reported to be retained in tilapia fish by Lin $\boldsymbol{e t}$ al., (1996) in fertilized earthen ponds. Phillips et al. (1990) also estimated that $15 \%$ of dietary phosphorus was retained in the fish biomass and $85 \%$ is lost to the aquatic environment. Wang et al. (2012) have found that $30 \%$ TP which entered the system as feed phosphorus were reversed into fish biomass. It seems that the nutrient retention in fish (mainly nitrogen and phosphorus) may differ under different conditions such as fish age, fish species, and environmental conditions (Avnimelech and Kochba 2009).

The total determined sludge at the end of fry production cycle was $9321.3 \pm 495.3 \mathrm{~g} /$ pond / 25 days, containing $50.0 \pm 2.4 \%$ of the applied dietary phosphorus. Moustafa et al. (2020) reported $32.62 \pm 14.46 \%$ of the applied dietary phosphorus was recovered in sludge of the Nile tilapia brood-stock cement ponds. According to Lall (1991) fish excrete dietary phosphorus in soluble form as dissolved inorganic $\mathrm{P}$ and particulate form settles at the fish pond bottom and referred as aquaculture sludge. Kibria et al., (1996) demonstrated that dietary phosphorus lose is a range of 80 and $95 \%$ with a decrease of temperature from 25 to $20^{\circ} \mathrm{C}$. Cripps and Bergheim, (2000) also reported that the main part of feed phosphorus, $30 \%-84 \%$ of the total phosphorus (TP), is in un-dissolved fraction.

Total water phosphorus in the present study was found to be $1.92 \pm$ $0.13 \mathrm{mg} / \mathrm{L}$ accounting for $25.8 \pm 1.5 \%$ of the applied dietary phosphorus. Moustafa et al. (2020) found that the total phosphorus water was 0.16 $\pm 0.05 \mathrm{mg} \mathrm{P} / \mathrm{L}$ representing of $50.22 \pm 16.63 \%$ of the applied dietary phosphorus in Nile tilapia brood-stock ponds. These differences can be explained partially to the differences in the applied amount of feeds as well as to the differences in the phosphorus content in the applied feeds. Lower phosphorus percent that is exported by effluent (11\% of TP entered the system in the form of feed) were reported by Boyd and Queiroz (2001) and Osti et al., (2018). However, Wang et al. (2012) found that $70 \% \mathrm{TP}$ which entered the system in the form of feed were 
released to the environment, which is in consistent with the present study by combining the effluent water phosphorus and the sludge phosphorus. Generally, total phosphorus at a concentration of $0.1-0.15 \mathrm{mg} / \mathrm{L}$ in the aquaculture effluent may results in eutrophication in the received water bodies as reported by (Warren-Hansen 1982; Alabaster 1982).

Dissolved organic phosphorus (DOP) in the present study accounted for $0.14 \pm 0.04 \mathrm{mg} / \mathrm{L}$ or $1.8 \pm 0.6 \%$ of the applied dietary phosphorus. Moustafa et al. (2020) found that the dissolved organic phosphorus to represent $16.47 \pm 7.69 \%$ of the applied dietary phosphorus. Also, lower ortho-phosphorus \% was found in the present study $(2.9 \pm 0.3 \%$ of the applied dietary phosphorus) than that reported by Moustafa et al. (2020) in the Nile tilapia brood-stock suggesting high pressure on both the OP and DOP in the present study through the phytoplankton as well as the microbial population. Relative high DOP in the present study can be partially explained by the bacterial activities that are supported by the nitrification process as well as other processes (de-nitrification and anammox) that results in N volatilization. Feuillade and Dorioz (1992) reported that there is a large bacterial population capable of taking up liberated soluble reactive phosphorus in natural water samples and turn it into dissolved organic phosphorus (DOP). Matsumoto (1985); Ogura (1985), elucidated that the organic phosphorus produced by in situ biological processes is repeatedly utilized in the ecosystem through remineralization and recycling that can render phosphorus uptake rate larger than $\mathrm{P}$ input up to 20 -folds. The high DIN : $\mathrm{P}$ ratio in the present study suggesting that phosphorus acts as a limiting factor in these Nile tilapia ponds for phytoplankton.

\section{CONCLUSIONS}

A better understanding of the $\mathrm{N}$ and $\mathrm{P}$ transformations may lead to practical ways to improve fish growth, maintaining pond water quality, and enhance effluent quality as well as efficient utilization of aquaculture wastes, either dissolved or solid wastes. As, improved fish feeds and efficient feeding practices can increase $\mathrm{N} \& \mathrm{P}$ recovery in fish, which in turn maintain water quality within the fry ponds for longer period and subsequently reduce the water consumption in fry rearing period. The results showed that the $\mathrm{P}$ is a limiting factor in the fry pond's effluent, which results in relatively low $\mathrm{N}$ recovery in the system. So, we can enhance $\mathrm{N}$ recovery by adding $\mathrm{P}$ in these ponds, which will stimulate phytoplankton growth and reduce $\mathrm{N}$ volatilization.

The second path of nutrients loss is atmosphere through $\mathrm{NH}_{3}$ volatilization and denitrification, which was high in fry ponds. This 
shows that the effluent of Nile fry rearing pond threatens environment more than the Nile tilapia brood-stock ponds, where it is richer in nutrients as there is more nitrification and denitrification processes that produce $\mathrm{N}_{2} \mathrm{O}$ to the atmosphere. So, it is necessary to search for efficient mean to control emission $\mathrm{N}_{2} \mathrm{O}$ and utilize nutrients in the aquaculture effluent. An efficient choice to achieve that is applying fish/aquatic plants integration system, through which aquatic plant consume these nutrients and turn them into valuable economic biomass (Ali et al., 2020) and at the same time maintain the water quality within ponds for longer time and subsequently maximize the water use efficiency in fish hatcheries.

The third portion of nutrients loss is through accumulation as solid wastes in the fish sludge form. Recently, Gomha et al. (2020) proved the vermicomposting technology as an aquaculture sludge recycling approach. In the present study the produced sludge characterized with high $\mathrm{N}$ and $\mathrm{P}$ content that may improve the quality of the produced vermicompost fertilizer. This vermicmopost fertilizer can be utilized in microalgae production, such as Spirulina platensis, as a cheaper alternating of chemical fertilizers, moreover, it enhances the quality of produced microalgae (Abd - El hay et al., 2019) or in fertilizing fish pond as well as agricultural land.

In this sense, it is recommended to use the effluent of fry rearing pond in microalgae production or aquatic plant production (i.e. duckweed) as use the sludge of these ponds in producing vermicompost bio-fertilizer and earthworm.

\section{REFERENCES}

Abd - El hay R.A. E., Moustafa Y. T. A. and EL-Metwaly Essa E. M., 2019. The use of vermicompost in cultivation and production of Spirulina platensis. Egy. J. of Aquac. Vol 9 No (3): 1-12.

Alabaster J.S., 1982. Report of the EIFA Workshop on Fish-farm Effluents. FAO/EIFAC Tech. Pap. 41, 166p.

Ali A. A.A.; Moustafa Y.T.A., Ahmed S. M. and Gomha S.A.A., 2020. Duckweed as a biological filter in tilapia fish hatcheries and its impact on tilapia reproduction. Abbassa int. J. Aqua., 13(1): 117 -134.

APHA (American Public Health Association), 1985. Standard Methods for the Examination of Water and Wastewater. 16th ed. Washington, D.C. $1268 \mathrm{pp}$.

Arredondo-Figueroa J.L., Núñez-García L.G., Ponce-Palafox J.T. and De-Los Ángeles Barriga-Sosa I., 2015. Performance of Brooders, Fry and Growth of the Nile Tilapia (Oreochromis niloticus) Cultured in an 
Experimental Recirculating Aquaculture System. Agricultural Sciences, 6:1014-1022. http://dx.doi.org/10.4236/as.2015.69096.

Avnimelech Y., Kochba M., 2009. Evaluation of nitrogen uptake and excretion by tilapia in biofloc tanks, using ${ }^{15} \mathrm{~N}$ tracing. Aquaculture 287:163-168.

Avnimelech, Y., Ritvo G., 2003. Shrimp and fish pond soils: processes and management. Aquaculture 220, 549-567.

Boyd C.E. and Queiroz J.F., 2001. Nitrogen, phosphorus loads vary by system, USEPA should consider system variables in setting new effluent rules. Global Aquaculture Advocate, vol. 4, no. 6, pp. 84-86.

Boyd C.E., 1985. Chemical budgets for catfish ponds. Transactions of American Fisheries Society 114: 291-298.

Boyd C.E., Tucker C.S., 1995. Sustainability of channel catfish farming. World Aquac. 26, 45-53.

Boyd C.E., Tucker C.S., 1998. Pond Aquaculture Water Quality Management. Kluwer Academic Publishers, Nowell, MA, p. 700.

Boyd C.E., Tucker C.S., Mcnevin A., Bostick A. and Clay J., 2007. Indicators of resource use efficiency and environmental performance in fish and crustacean aquaculture. Reviews in Fisheries Science, vol. 15 , no. 4 , pp. 327-360.

Cripps S. J., and Bergheim A., 2000. Solids management and removal for intensive land-based aquaculture production systems. Aquacultural Engineering, 22, 33-56.

Dalsgaard T. and Thamdrup B., 2002. Factors Controlling Anaerobic Ammonium Oxidation with Nitrite in Marine Sediments. Applied and Envirnomental Micrbiology, 68(8): 3802-3808.

FAO 2020. The State of World Fisheries and Aquaculture.pp.206.

Ferber L. R., Levine S. N., Lini A.and Livingston G. P., 2004. Do cyanobacteria dominate in eutrophic lakes because they fix atmospheric nitrogen?. Freshwater Biology 49: 690-708.

Feuillade M., and Dorioz J.M., 1992. Enzymatic release of phosphate in sediments of various origins. Water Res. 26:1195-1201.

Findlay D.L., Hecky R.E., Hendze L.L., Stainton M.P., Regehr G.W., 1994. Relationship between $\mathrm{N}_{2}$-fixation and heterocyst abundance and its relevance to the nitrogen budget of lake 227. Can. J. Fish. Aquatic Sci. 51, 2254-2266. 
Gomha S.A.A., Moustafa Y.T. A., Mahmoud A. A., Batran A. M. M., (2020). The aptness of Nile Tilapia pond sludge as a bedding media for earthworm growth and vermicompost production. Abbassa Int. J. Aqua. 13(1): 135-156.

Gross A., Boyd C.E. and Wood C.W., 2000. Nitrogen transformations and balance in channel catfish ponds. Aquacul. Eng. 24:1-14.

Gross A., Boyd C.E., Wood C.W., 1999. Ammonia volatilization from freshwater fish ponds. J. Environ. Quality 28, 793-797.

Hargreaves J.A., 1995. Nitrogen biochemistry of aquaculture pond sediments. Ph.D. dissertation. Louisiana State University, LA.

Hendzel L.L., Hecky R.E., Findlay D.L., 1994. Recent changes of $\mathrm{N}_{2}-$ fixation in lake 227 in response to reduction of the N:P loading ratio. Can. J. Fish. Aquatic Sci. 51, 2247-2253.

Hepher B., 1988. Nutrition of pond fishes. Cambridge Univ. Press, Cambridge, NY, USA. 388 pp.

Higgins S. N., Paterson M.J., Hecky R. E., Schindler D. W., Venkiteswaran J. J., and Findlay D. L., 2018. Biological Nitrogen Fixation Prevents the Response of a Eutrophic Lake to Reduced Loading of Nitrogen: Evidence from a 46-Year Whole-Lake Experiment. Ecosystems 21: 1088-1100.

Jaroszynski L.W., Cicek N., Sparling R., Oleszkiewicz J.A., 2012. Impact of free ammonia on anammox rates (anoxic ammonium oxidation) in a moving bed biofilm reactor. Chemosphere 88:188-195. DOI: 10.1016/j.chemosphere.2012.02.085

Jimenez-Montealegre R., Avnimelech Y., Verreth J. A. J.\& Verdegem M.C. J., 2005. Nitrogen budget and fluxes in Colossoma macropum ponds. Aquaculture Research, 36: 8-15.

Kibria G., Nugegoda D., Lam P., Fairclough R., 1996. Aspects of phosphorus pollution from Aquaculture . Naga, The ICLARM Quarterly. 19, pp. 20-24. DOI: 10.13140/2.1.3762.5284

Kouba A., Lunda R., Hlavac D., Kuklina I., Hamackova J., Randak T., Kozak P., Koubova A., Buric M., 2018. Vermicomposting of sludge from recirculating aquaculture system using Eisenia andrei: Technological feasibility and quality assessment of end-products. Journal of Cleaner Production 177:665-673.

Lall S.P., 1991. Digestibility, metabolism and excretion of dietary phosphorus in fish. p. 163-185. In C.B. Cowey and C.Y. Cho (eds.) Nutritional strategies and aquaculture waste. Proceedings of the First 
International Symposium on Nutritional Strategies in Management of Aquaculture Waste. University of Guelph, Ontario, Canada.

Laws E.A. \& Bannister T.T., 1980. Nutrient- and light-limited growth of Thalassiosira fuviatilis in continuous culture, with implications for phytoplankton growth in the ocean. Limnology and Oceanography 25, 457-473.

Lin C. K., Yi Y. and Diana J. S., 1996. The effects of Pond Management Strategies on Nutrient Budgets: Thailand. Fourteenth Annual Technical Report, page 19-24. CRSP.

Lin C.K., and Yi Y., 2003. Minimizing environmental impacts of freshwater aquaculture and reuse of pond effluents and mud. Aquaculture; 226:57-68.

Matsumoto E., 1985. Budgets and residence times of nutrients in Tokyo Bay, p. 127-136. In A.C. Siglco and A. Hattori (eds.), Marine and estuarine geochemistry. Lewis.

Morris D.P . \& Lewis W.M. Jr., 1988. Phytoplankton nutrient limitation in Colorado mountain lakes. Freshwater Biology, 19, 315-327.

Moustafa Y. T.A., Ali A. A. A., Gomha S.A.A.and Glal E. M., 2020. Nitrogen and Phosphorus budget for Nile tilapia hatchery. Egyptian J. for Aqua., 10 (1) :1-22.

Muendo P. N., Verdegem M. C. J., Stoorvogel J. J., Milstein A., ElNaggar G., Duc P.M.and Verreth J. A.J., 2014. Sediment Accumulation in Fish Ponds; Its Potential for Agricultural Use. International Journal of Fisheries and Aquatic Studies; 1(5): 228-241.

Naylor R.L., Goldburg R.J., Primavera J. H., Kautsky N., Beveridge M.C.M., Clay J., Folke C., Lubchenco J., Mooney H., and Troell M., 2000. Effect of aquaculture on world fish supplies. Nature 405:1,0171.024 .

Oenema O., Witzke H. P., Klimont Z., Lesschen J.P. and Velthof G. L., 2009. Integrated assessment of promising measures to decrease nitrogen losses from agriculture in EU-27 Agric. Ecosyst. Environ. 133(3/4): 280-288.

Ogura N., 1985. Tokyo Bay (chemistry), p.312-372. In The Oceanographic Society of Japan (ed.), Coastal oceanography of Japanese islands. Tokai Univ. Press.

Osti J. A. S., Moraesb M. A. B., Carmob C. F. and Mercante C. T. J., 2018. Nitrogen and phosphorus flux from the production of Nile 
tilapia through the application of environmental indicators. Brazilian Journal of Biology, 78(1):25-31.

Philips M.J., Beveridge M.C.M., Macintosh D.J., 1990. The impact of aquaculture on the coastal environment, p. 537-545. Proceedings of ISCZC 1988, China Ocean Press, Beijing.

Schroeder G.L., Alkon A. \& Laher M., 1991. Nutrient flow in pond aquaculture systems. In: Aquaculture and Water Quality (ed. by D.E. Brune \& J.R. Tomasso), pp. 498-505. World Aquaculture Society, Baton Rouge, LA, USA.

Schwartz M.F. and Boyd C.E., 1994. Effluent quality during harvest of channel catfish from watershed ponds. Progressive Fish-culturist 56: 25-32.

Summerfelt S. T. and Vinci B. J., 2003. Best Waste Management Practices for Recirculating Systems. In: Summerfelt, R. C.; Clayton, R. D. (Eds.). Aquaculture Effluents: Overview of EPA Guidelines and Standards and BMPs for Ponds, Raceways, and Recycle Systems. Publication Office, North Central Regional Aquaculture Center, Iowa State University, Ames, Iowa, 111-133 [online], [cited 21 November 2016].

Summerfelt S. T., Binkowski F. B., Malison J.A., and Reinemann D. J., 2001. Aquacultural wastes and effluents: their characteristics, removal and beneficial uses. Available at: https://www.ncrac.org/files/project/files/wastesprojectoutl ine3.pdf.

Tavares, S. and Boyd C.E., 2003. Comparison of a dry ash method with perchloric acid digestion for total phosphorus analysis of pond sediment. J. Aquaculture in the Tropics, 18: 239-244.

Thoman E.S., Ingall E. D., and Davis D. A., 2001. Arnold C. R. A nitrogen budget for a closed, recirculating mariculture system. Aquacultural Engineering 24195 - 211.

Wang X., Olsen L.M., Reitan K.I. and Olsen Y., 2012. Discharge of nutrient wastes from salmon farms: environmental effects, and potential for integrated multi-trophic aquaculture. Aquaculture Environment Interactions, 2 (3): 267-283.

Warren-Hansen I., 1982. Evaluation of matter discharged from trout farming in Denmark. Report of the EIFAC Workshop on Fish-Farm Effluents. FAO/EIFAC Tech Pap. 41:57-63. 
Yone Y. and Toshima T., 1979. The utilization of phospohorus in fish meal by carp and black sea bream. Bull. Jap. Soc. Sci. Fish. 45:753756.

Zhang Y., Bleeker A.and Liu J., 2015. Nutrient discharge from China's aquaculture industry and associated environmental impacts. Environ. Res. Lett. 10:1-14, 045002.

Zhang Y., Luan S., Chen L.and Shao M., 2011. Estimating the volatilization of ammonia from synthetic nitrogenous fertilizers used in China J. Environ. Manage. 92: 480-93.

Zimmo, O.R., van der Steen N.P., and Gijzen H.J., 2004. Nitrogen mass balance across pilot-scale algae and duckweed-based wastewater stabilisation ponds. Water Res. 38, 913-920. 


\section{دراسة تحولات صور النيتروجين والقوسفور في أحواض زريعة البلطي النيلي الأسمنتية}

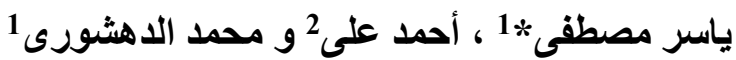

1- قسم الليمنولوجى 2- قسم الفسيولوجى و التفريخ، المعمل المركزى لبحوث الثروة السمكية،

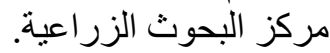
3- قسم تكنولوجيا التسميد، المركز القومى للبحوث.

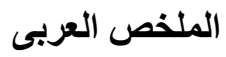

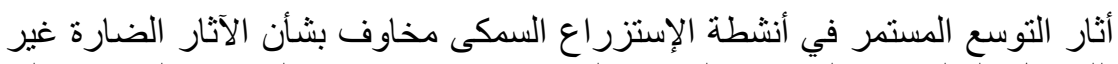

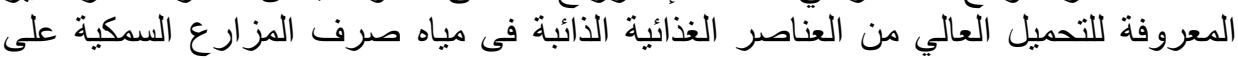

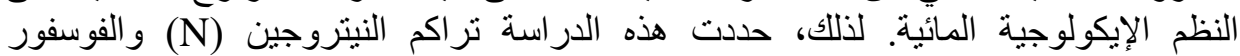

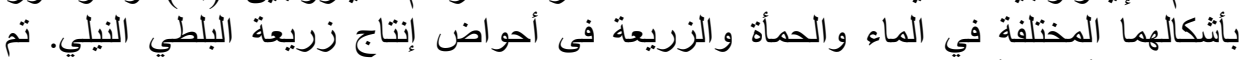

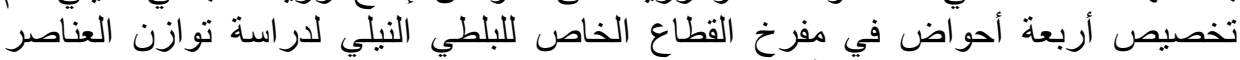

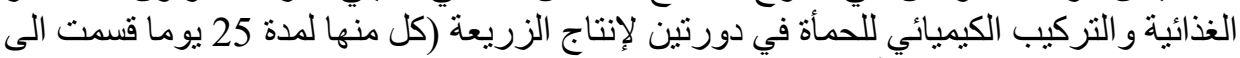

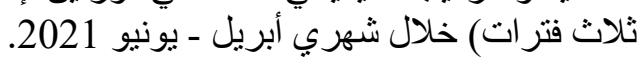

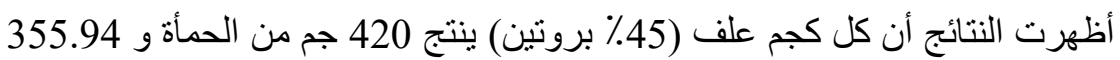

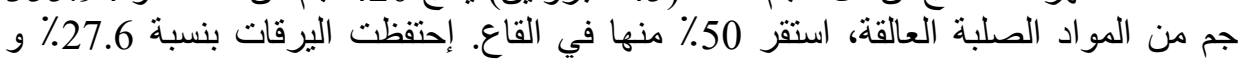

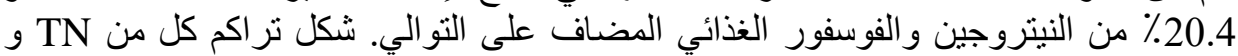

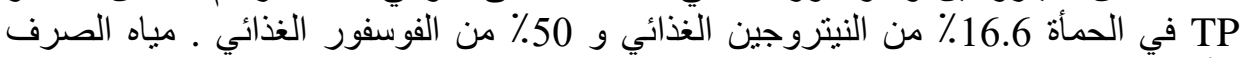

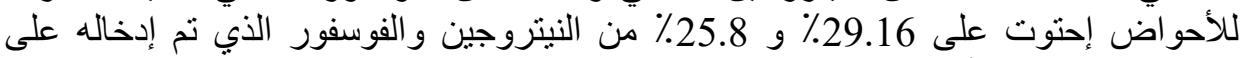

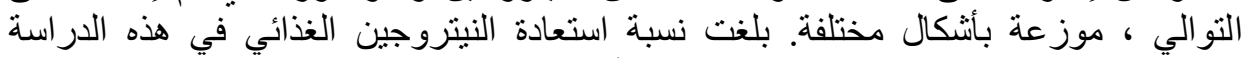

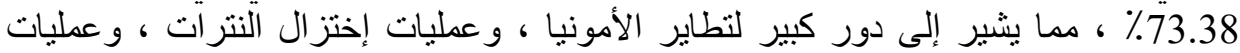

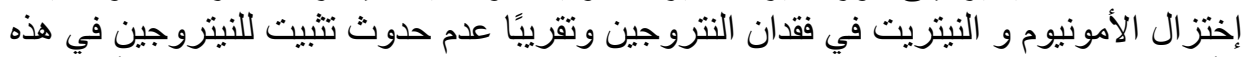

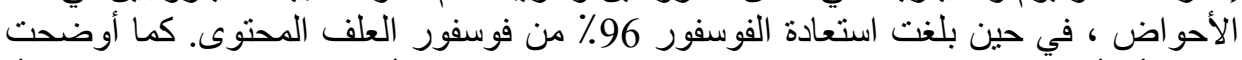

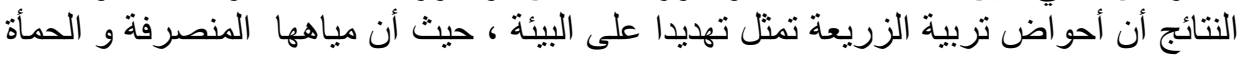
المنتجة منها تكون ثرية بالمغذيات.

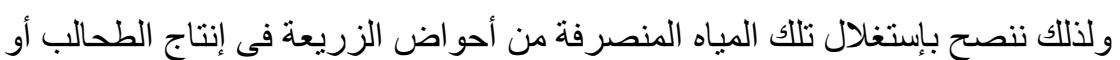

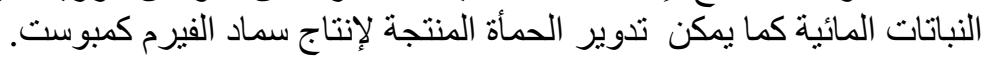

